\title{
MENGGAGAS PERENCANAAN KURIKULUM SEKOLAH UNGGUL
}

\author{
ZAINUR ROZIQIN \\ Universitas Nurul Jadid Paiton Probolinggo \\ Email: roziqinzainur46@gmail.com
}

\begin{abstract}
This paper aims to find out how the curriculum and how the actual curriculum planning is offered by superior schools. Creating a quality curriculum for superior schools is very important, because the curriculum is a door to guarding the direction of educational goals to be brought, a leader of school institutions and other institutions must have the consideration and understanding of competent management to get a quality and superior curriculum. the initial stage in the management function that must be mastered by the leadership of the school institution management is the planning function which becomes the initial foundation for making the curriculum in line with the vision and mission of the institution. Therefore curriculum planning in superior schools is very important in order to get the real label that schools that use planning in their curriculum are truly superior schools. The results of the analysis of the authors describe that some of the planning used by superior schools is to emphasize the formation of quality.
\end{abstract}

Keyword: curriculum, Planning, Superior schools.

\begin{abstract}
Abstrak
Tulisan ini bertujuan untuk mengetahui bagaimana kurikulum beserta bagaimana perencanaan kurikulum sebenarnya yang ditawarkan oleh sekolah unggul. Membuat kurikulum yang bermutu bagi sekolah unggul sangatlah penting, karena kurikulum merupakan pintu untuk mengawal arah tujuan pendidikan yang akan dibawa, seorang pemimpin lembaga sekolah maupun lembaga selainnya haruslah memiliki pertimbangan dan pemahaman manajeman yang kompeten agar mendapatkan kurikulum yang bermutu dan unggul. tahap awal pada fungsi manajemen yang harus dikuasai oleh pihak pimpinan pengelola lembaga sekolah adalah fungsi perencanaan yang menjadi pondasi awal untuk membuat kurikulum yang searah dengan visi-misi pada lembaga tersebut. Oleh karenanya perencanaan kurikulum pada sekolah unggul sangatlah penting agar mendapatkan label sesungguhnya bahwa sekolah yang menggunakan perencanaan dalam kurikulumnya memang betul-betul sekolah unggul. Hasil dari analis penulis mendeskripsikan bahwa beberapa perencanaan yang digunakan oleh sekolah unggul adalah dengan menekankan kepada terbentuknya mutu.
\end{abstract}

Kata Kunci: kurikulum, perencanaan, sekolah unggul. 


\section{PENDAHULUAN}

Kurikulum ialah salah satu komponen yang memiliki peran penting didalam sistem lembaga pendidikan, sebab didalam kurikulum tidak hanya merumuskan tentang tujuan yang seharusnya dicapai untuk akhirnya akan memperjelas arah tujuan pendidikan, dan pada akhirnya akan memberikan pengalaman pada individu peserta didik. Pendidikan dan kurikulum merupakan dua fungsi untuk menyiapkan peserta didik dikehidupan bermasyarakat yang lebih baik. Agar manfaat kurikulum bisa dirasakan oleh masyarakat yang bernaung pada lembaga pendidikan nasional.

Manusia akan menjadi manusia seutuhnya apabila mendapatkan pendidikan. Baik mejalani proses pendidikan secara formal maupun non formal ataupun proses pendidikan selain formal dan informal, dengan begitu perlulah kurikulum yang bisa untuk menyelesaikan permasalahan-permasalahan yang ada dengan kurikulum yang tepat sebagai persiapan terhadap generasi penerus bangsa yang berkarakter merupakan kebutuhan yang amat vital.

Lembaga Pendidikan, utamanya yang bersifat formal, adalah suatu hal proses yang tidak dapat dipisahkan dengan kurikulum. Kurikulum adalah hal penting yang menentukan keberhasilan suatu proses pendidikan. Kurikulum pendidikan yang terfokus kepada satu pelajaran umum saja maka akan berakibat keringnya pengetahuan agama. Demikian halnya dengan kurikulum pendidikan agama seperti "pesantren" menjadikan pengetahuan agama sebagai ilmu yang pertama dan mengesampingkan pendidikan umum, hal tersebut akan membuat peserta didik akan kering terhadap ilmu umum yang sangat penting bagi dunia globalisasi ini. Dengan demikian Kurikulum sebagai salah satu komponen penting dalam pendidikan perlu dikelola agar dapat memberikan kontribusi terhadap peningkatan mutu pendidikan di sekolah. ${ }^{2}$

Setiap instansi pendidikan, seperti pendidikan yang berada di lingkungan keluarga, lingkungan sekolah (pendidikan formal) maupun pendidikan non formala (luar sekolah), dari jenjang pendidikan dasar sampai perguruan tinggi memiliki tugas kewajiban melaksanakan pendidikan selain untuk mencapai tujuan institusional, juga mengemban dharma untuk merealisasi tujuan pendidikan nasional, yaitu salah satunya yang terpenting adalah menyusun kurikulum guna mewujudkan tujuan kelembagaan maupun tujuan nasional selain itu kurikulum menjadi alat dan pedoman penyelanggaraan pendidikan melalui proses belajar mengajar disekolah maupun luar sekolah dengan kata lain "kurikulum jantungnya pendidikan dan pengajaran ". 3

Namun sebelum itu suatu lembaga madrasah pasti memiliki Perencanaan yang terjadi pada semua kegiatan. Perencanaan adalah proses awal didalam pengelolalaan setiap sesuatu karena perencanaan memegang peran penting

\footnotetext{
${ }^{1}$ Ahmad Fauzi et al., "E-Learning in Pesantren : Learning Transformation Based on the Value of Pesantren," Journal of Physics: Conf. Series 11141114 (2018): 1-6, https://doi.org/10.1088/17426596/1114/1/012062.

${ }^{2}$ Norma Chunnah Zulfa, 'Manajemen Kurikulum Madrasah Aliyah Program Keagamaan', Jurnal Akuntabilitas Manajemen Pendidikan, Vol. 05 No. o2 (2013), 219.

${ }^{3}$ Muhammad Arif, 'Kurikulum Madrasah Dan Sekolah Di Indonisia', Makalah Pengembangan Kurikulum Dan Pembelajaran PAI, (2018), 04.
} 
dibandingkan dengan fungsi manajemen yang lainnya seperti pengorganisasian dan sebagainya yang kesemuanya fungsi tersebut hanyalah pengaktualisasian dari perencanaan.

Perancanaan terhadap kurikulum sebagai penopang dalam mensukseskan proses pendidikan merupakan bagian penting dalam proses terjadinya pendidikan, tanpa adanya kurikulum proses pendidikan akan terlihat tidak teratur, oleh karenanya kurikulum adalah sebagai alat untuk mencapai tujuan serta menjadi pedoman dalam dunia pendidikan terutama ketika kegiatan belajar mengajar (KBM) di dalam berbagai tingkat sekolah maupun madrasah. ${ }^{4}$ oleh karena itu pembahasan ini difokuskan terhadap bagaimana hakikat sebenarnya perencanaan kurikulum di sekolah yang terfokuskan terhadap materi bahan pembelajaran umum, serta bagaimana menggagas perencanaan kurikulum di lembaga sekolah.

\section{PEMBAHASAN}

\section{Hakikat Perencanaan Kurikulum di Sekolah}

Dalam dunia pendidikan biasanya kurikulum dikenal dengan beberapa mata pelajaran disekolah yang harus ditempuh oleh anak didik untuk mencapai jenjang tertentu dan mendapatkan sertifikat hasil belajar atau ijazah. Artinya, kurikulum merupakan keseluruhan mata pelajaran yang disusun dan diterapkan dalam proses belajar siswa di sekolah.

Asal Istilah kurikulum berasal dari bahasa latin Curriculum awalnya mempunyai pengertian a running course dan dalam bahasa Perancis yakni courier yang berarti to run artinya berlari. ${ }^{5}$ Menurut Subandijah, kurikulum merupakan kegiatan belajar mengajar yang dikelola dengan perencanaan dibawah bimbingan sekolah untuk diprogramkan kepada peserta didik baik dalam sekolah maupun diluar sekolah. $^{6}$

seiring perkembangan zaman, dunia pendidikan juga terus mengalami perkembangan dan atas kontribusi pemikiran tokoh-tokoh pendidikan mengenai kurikulum, sehingga kurikulum kini tidak hanya memiliki arti sempit yang di dalamnya hanya memuat jumlah mata pelajaran melainkan memiliki arti luas seperti kurikulum yang diartikan oleh Menurut Glatorn kurikulum adalah perencanaan yang disiapkan sebagai pedoman belajar dalam sekolah yang pada umumnya dimunculkan dalam dokumen dan diterapkan dalam kelas. ${ }^{7}$

Di dalam Undang-Undang No.20 Tahun 2003 terkait Sistem Pendidikan Nasional kurikulum merupakan satu rancangan dan pengaturan mengenai isi dan bahan pelajaran serta cara yang digunakan sebagai pedoman penyelenggaraan kegiatan pembelajaran untuk mencapai tujuan pendidikan tertentu. ${ }^{8}$

\footnotetext{
${ }^{4}$ Hasan Baharun, Pengembangan Kurikulum : Teori Dan Praktik (Konsep, Prinsip, Model, Pendekatan Dan Langkah-Langkah Pengembangan Kurikulum PAI) (Yogyakarta: Cantrik Pustaka, 2017). 39

${ }^{5}$ Baharun. 17

${ }^{6}$ Subandijah, Pengembangan Dan Inovasi Kurikulum (Jakarta: PT. Raja Grafindo Persada, 1993). 2.

${ }^{7}$ Eko Supriyanto, Pengembangan Kurikulum Pendidikan Cerdas Istimewa (Yogyakarta: Pustaka Pelajar, 2012). 48.

8 Wina Sanjaya, Kurikulum Dan Pembelajaran, (Jakarta: Kencana Prenada Media Group, 2008). 8
} 
Pengertian kurikulum yang disebutkan di atas memiliki perbedaan namun tetap sama dalam substansinya yang harus tetap mendapatkan titik temu, bahwa di satu pihak ada yang menekankan pada proses dan pengalaman, dan di lain pihak lebih menekankan pada isi pelajaran.

Pengertian awal tentang kurikulum lebih menitik beratkan pada isi pelajaran dalam arti beberapa pelajaran di instansi sekolah yang harus diikuti agar mendapatkan surat keterangan menyelesaikan studi, juga keseluruhan pelajaran yang disajikan oleh suatu lembaga pendidikan. ${ }^{9}$

Dan didalam hal lain, kurikulum dapat dijadikan ukuran kualitas proses dan keluaran pendidikan yang dijalankan. Dalam suatu kurikulum sekolah telah tergambar tentang berbagai hal pengetahuan, keterampilan, sikap serta nilai-nilai yang diharapkan dimiliki oleh setiap lulusan suatu sekolah. Akan tetapi, kurikulum bukanlah merupakan satu-satunya factor penentu kualitas (keberhasilan) suatu sekolah. Masih terdapat berbagai factor lain yang turut menunjang kualitas atau keberhasilan kegiatan pendidikan yang dijalankan, seperti masalah sarana dan prasarana, situasidan kondisi lingkungan, kualitas guru sebagai pelaksana pendidikan dan sebagainya. ${ }^{10}$

Perencanaan (planning) merupakan suatu langkah persiapan dalam pelaksanaan suatu pekerjaan untuk mencapai tujuan perencanaan. Pelaksanaan suatu kegiatan akan mengalami kesulitan dan bahkan kegagalan dalam mencapai tujuan yang diinginkan bila tanpa perencanaan. Perencanaan kurikulum merupakan langkah awal kegiatan pelaksanaan kurikulum di lapangan. ${ }^{11}$

Definisi tentang perencanaan (Planning) banyak dikemukakan oleh para tokoh, di antaranya adalah Kaufman yang menyatakan bahwa perencanaan adalah suatu proyeksi tentang apa yang diperlukan dalam rangka mencapai tujuan yang absah dan bernilai. ${ }^{12}$

Sementara menurut Peter F. Olivia, Perencanaan kurikulum terjadi pada berbagai tingkatan. Para pegawai, staf kedisiplinan maupun staf guru dan yang lainya ikut serta terlibat dalam perencanaan kurikulum, akan tetapi guru yang paling berpartisipasi dalam kurikulum. tingkat perencanaan dimana fungsi guru dapat dikonseptualisasikan sebagai sosok yang ditunjukkan. ${ }^{13}$

Dalam perencanaan kurikulum di sekolah, terdapat beberapa aspek yang harus diperhatikan. Aspek-aspek yang menjadi karakteristik perencanaan kurikulum di sekolah maupun di madrsah tersebut sebagai berikut:

1. Perencanaan kurikulum harus berdasarkan konsep yang jelas tentang berbagai hal yang menjadikan kehidupan lebih baik, karakteristik masyarakat sekarang dan masa depan, serta kebutuhan dasar manusia.

2. Perencanaan kurikulum harus dibuat dengan mempertimbangkan dan mengoordinasi unsur esensial belajar mengajar efektif dalam kerangka kerja yang komprehensif.

\footnotetext{
9 S. Nasution, Asas-Asas Kurikulum, (Bandung: Jemmars, 1982). 5.

${ }^{10}$ S. Nasution, Kurikulum Dan Pengajaran, (Jakarta, PT. Bumi Aksara, 1995). 7.

${ }^{11}$ H. Dakir, Perencanaan Dan Pengembangan Kurikulum, (Jakarta, PT. Rineka Cipta, 2004), 117.

${ }^{12}$ Harjanto, Perencanaan Pengajaran, (Jakarta, PT. Rineka Cipta, 2003) 2.

${ }^{13}$ Peter F. Olivia, Development The Curriculum, (New York: Pearso Education,Inc, 2004). 46-47.
} 
3. Perencanaan kurikulum harus bersifat antisipasif maupun reaktif. Pendidikan harus responsif terhadap kebutuhan siswa, agar membantu peserta didik menuju kehidupan yang baik.

4. tujuan-tujuan pendidikan selayaknya menekankan kepada kebutuhan di masyarakat.

5. Rumusan berbagai tujuan pendekatan harus diperjelas dengan ilustrasi konkrit, agar dapat digunakan dalam pengembangan rencana kurikulum yang spesifik . jika tidak, persepsi yang muncul kurang jelas dan kontradiktif.

6. Dalam perencanaan kurikulum, evaluasi secara kontinue terhadap keputusan yang sudah direncanakan terhadap kurikulum, yang juga meliputi analisis terhadap proses dan konten kurikulum.

7. Berbagai jenjang sekolah, dari Taman Kanak-kanak sampai Perguruan Tinggi, hendaknya merespon dan mengakomodasi perubahan, pertumbuhan, dan perkembangan siswa. untuk itu, perlu direfleksikan organisasi dan prosedur secara bervariasi. ${ }^{14}$

Hal tersebut harus di perhatikan oleh pihak terkait terlebih bagi top leader dari masing-masing sekolah agar dalam perencanaan kurikulum mendapatkan hasil yang memberikan nilai untung bagi seluruh pihak yang berkebutuhan di instansi sekolah tersebut.

Tidak kalah penting juga di dalam proses merencanakan kurikulum sekolah selain memperhatikan aspek-aspek harus juga memperhatikan beberapa asas. asas atau landasan kurikulum adalah seperti fondasi sebuah bangunan. Apa yang akan terjadi seandainya sebuah gedung yang menjulang tinggi berdiri di atas fondasi yang rapuh. Tentu saja bangunan itu tidak akan bertahan lama. Oleh sebab itu, sebelum sebuah bangunan gedung, fondasi yang kokoh terlebih dahulu.

Sama halnya pembangunan sebuah gedung, maka merecanakan sebuah kurikulum juga harus didasarkan pada fondasi yang kuat. Kesalahan menentukan dan menyusun fondasi kurikulum berarti kesalahan dalam menentukan kebijakan dan implementasi pendidikan. ${ }^{15}$

Di bawah ini adalah beberapa asas di dalam perencanaan kurikulum di sekolah sebagai berikut: ${ }^{16}$

\begin{tabular}{|c|l|}
\hline Objektivitas & $\begin{array}{l}\text { Planning kurikulum haruslah memberikan } \\
\text { kejelasan disesuaikan dengan tujuan } \\
\text { pendidikan nasional di indonisia, serta data- } \\
\text { data yang diinput haruslah konkrit atau real. }\end{array}$ \\
\hline \multirow{3}{*}{ Keterpaduan } & $\begin{array}{l}\text { Planning kurikulum haruslah sesuai dengan } \\
\text { beberapa jenis yang mendukung mulai dari } \\
\text { disiplin ilmu, keterpaduan antara stekholder } \\
\text { eksternal maupun eksternal, dan juga }\end{array}$ \\
\hline
\end{tabular}

\footnotetext{
${ }^{14}$ Oemar Hamalik, "Dasar-Dasar Pengembangan Kurikulum," Bandung: PT. Remaja Rosdakarya, 2007. 173-174.

${ }^{15}$ Wina Sanjaya, Kurikulum Dan Pembelajaran, (Jakarta: Kencana Prenada Media Group, 2008). 31.

${ }^{16}$ Oeamar Hamalik, Manajemen Pengembangan Kurikulum (Bandung: PT Remaja Rosdakarya, 2012). 155-156.
} 


\begin{tabular}{|c|c|}
\hline & $\begin{array}{l}\text { keterpaduan isi kurikulum } \\
\text { pengaktualisasian di lapangan. }\end{array}$ \\
\hline Manfaat & $\begin{array}{l}\text { Planning kurikulum memberikan beberapa } \\
\text { gambaran yang bermanfaat sebagai pijakan } \\
\text { untuk meberikan kebijakan dididalam } \\
\text { evaluasi proses penyelenggaraan pendidikan }\end{array}$ \\
\hline Efisiensi dan Efektivitas & $\begin{array}{l}\text { Planning kurikulum dalam menghasilkan } \\
\text { tujuan pendidikan yang maksimal berasakan } \\
\text { terhadap efesiensi keuangan dan efektifitas } \\
\text { waktu. }\end{array}$ \\
\hline Kesesuaian & $\begin{array}{l}\text { Planing kurikulum di se arahkan dengan visi- } \\
\text { misi akan diarahkan kemana potensi peserta } \\
\text { didik serta mengikuti perubahan zaman } \\
\text { milenial yang sangat membutuhkan ilmu } \\
\text { teknologi. }\end{array}$ \\
\hline Keseimbangan & $\begin{array}{l}\text { Planning kurikulum mengasaskan } \\
\text { keseimbangan pada seluruh komponen yang } \\
\text { mendukung dari kemampuan SDM sampai } \\
\text { perlengkapan untuk melaksanakan kegiatan. }\end{array}$ \\
\hline Kemudahan & $\begin{array}{l}\text { Perencanaan kurikulum memberikan } \\
\text { kemudahan bagi para pemakainya yang } \\
\text { membutuhkan pedoman berupa bahan kajian } \\
\text { dan metode untuk melaksanakan proses } \\
\text { pembelajaran. }\end{array}$ \\
\hline Berkesinambungan & 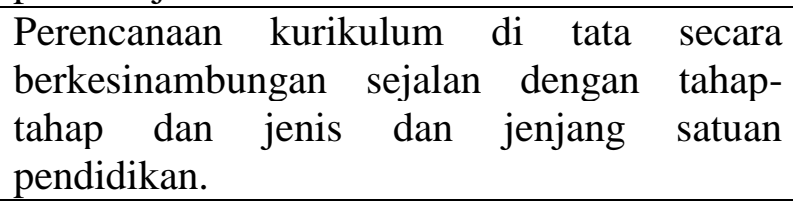 \\
\hline Pembakuan & $\begin{array}{l}\text { Perencanaan kurikulum dilakukan sesuai } \\
\text { dengan jenjang dan jenis satuan pendidikan, } \\
\text { sejak dari pusat, propinsi, kabupaten / } \\
\text { kotamadya. }\end{array}$ \\
\hline Mutu & $\begin{array}{l}\text { Planning kurikulum memberikan pemilihan } \\
\text { kepada seluruh perangkat pembelajaran yang } \\
\text { bermutu, untuk meberikan kepuasan dalam } \\
\text { memberikan lulusan yang berkualitas dan } \\
\text { kompeten. }\end{array}$ \\
\hline
\end{tabular}

Dalam hal membangun asas ini pihak pimpinan harus memiliki analis yang tepat sehingga dalam membangun asas tersebut bisa menjadikan sebuah instansi sekolah bisa bersaing dengan sempurna Berangkat dari hal tersebut, dapat diketahui bahwa lembaga pendidikan Islam akan memiliki competitive adventage (keunggulan dalam bersaing) jika manajamen kinerjanya di samping aspek yang lain dikelola dengan baik, sesuai dengan situasi dan latar belakang yang mengelilinginya. 
Setelah mengetahui asas-asas dari perencanaan kurikulum di sekolah selanjutnya adalah perlunya pimpinan di dalam menyusun perencanaan kurikulum dengan teliti, menyeluruh dan rinci, karena mengandung multi fungsi sebagai berikut: ${ }^{17}$

1. Perencanaan kurikulum berfungsi sebagai alat manajemerial dan pedoman, yang berisi sebagai petunjuk tentang jenis dan sumber yang dibutuhkan, media penyampaiannya, tindakan yang perlu dilakukan, sumber biaya, tenaga, sarana yang diperlukan, sistem kontrol dan evaluasi, peran unsur-unsur ketenangan untuk mencapai tujuan manajemen.

2. Perencanaan kurikulum ialah sebagai penggerak roda dalam organisasi dan tata laksananya agar terciptanya perubahan di dalam masyarakat sesuai dengan tujuan organisasi itu tersendiri.

3. Perencanaan kurikulum berfungsi sebagai motivator untuk menjalankan sistem yang ada di dalam lembaga pendidikan sehingga mencapai hasil maksimal.

Namun terciptanya suatu proses perencanaan kurikulum di sekolah yang efektif dan efesien tergantung bagaimana seorang top leader menggerakkan seluruh kompenen yang ada. dapat diketahui bahwa fungsi utama pimpinan pada satuan pendidikan, seperti kepala sekolah adalah menciptakan situasi belajar mengajar sehingga guru-guru dapat mengajar dan murid-murid dapat belajar dengan baik. Dalam pelaksanaan tersebut, pimpinan mempunyai tanggung jawab dalam melaksanakan administrasi lembaga pendidikan sehingga tercipta situasi belajar mengajar (teaching learning) yang baik dan melakukan supervisi yang nantinya kompetensi guru bertambah dan menjadi professional.

Seorang pemimpin harus selalu memperbaiki mutu pendidikan yang di dalamnya ada perencanaan kurikulum. Sesungguhnya, mutu pendidikan adalah factor kunci dalam kompetisi, baik tingkat lokal, regional, nasional dan internasional di era globalisasi ini. Mutu lulusan dan pelayanan yang dihasilkan oleh berbagai lembaga pendidikan, ditentukan oleh kompetisi manajerial, kepemimpinan, visi dan integritas kepribadian para manajer, guru-guru dan pegawai dalam mengelola pendidikan. Karena itu, tuntutan perbaikan mutu lembaga pendidikan perlu direspon dan dijadikan hal utama dalam penyusunan strategi lembaga pendidikan nasional untuk memenuhi permintaan (demand) SDM unggul sebagai subjek pembangunan hari ini dan mendatang. ${ }^{18}$

Oleh sebab itu perencanaan kurikulum bagi sekolah sangatlah penting melihat persaingan antar lembaga sekolah dan madrasah yang sangat ketat sehingga menuntut terhadap Mutu pendidikan itu sendiri dan pada akhirnya akan memberikan pelayanan yang memuaskan (castemur satisfaction) bagi konsumen jasa pendidikan.

\footnotetext{
${ }^{17}$ Oeamar Hamalik, Manajemen Pengembangan Kurikulum. 152.

${ }^{18}$ Zamroni Hasan Baharun, Manajemen Mutu Pendidikan : Ikhtiar Dalam Meningkatkan Mutu Pendidikan Madrasah Melalui Pendekatan Balanced Scorecard (Tulungagung: Akademia Pustaka, 2017).
} 


\section{Dimensi Perencanaan Kurikulum di Sekolah}

Beberapa tokoh mengemukakan dimensi kurikulum mulai dari kurikulum sebagai ide atau persepsi, kurikulum sebagai proses kegiatan, kurikulum sebagai sistem, kurikulum sebagai suatua rencana tertulis, kurikulum sebagai suatu hasil belajar, dan lain sebagainya. Dari hal tersebut dapat disimpulkan bahwa paling tidak ada enam dimensi kurikulum yang dikemukakan oleh beberapa tokoh yaitu :

1. Kurikulum Sebagai Suatu Ide.

Konsep atau ide akan terus bergerak, artinya akan terus meberikan perubahan sesuai dengan tuntutan zaman, minat dan kebutuhan peserta didik, tuntutan masyarakat sosial, ilmu pengetahuan dan teknologi. Gagasan maupun ide hanyalah terdapat terhadap seseorang yang berproses dalam dunia pendidikan, apakah secara langsung maupun tidak langsung,seperti halnya pimpinan dinas pendidikan, pimpinan sekolah, guru, peserta didik maupun orang tua siswa. Pada saatg seorang memikirkan arah tujuan pendidikan seorang guru memikirkan proses pembalajaran yang akan di arahkan kepada guru untuk mengajar peserta didik maka disitulah dimensi kurikulum sebagai suatu ide atau konsepsi. Menurut mereka paling tidak itulah konsepsi kurikulum. Setiap orang pasti berbeda didalam ide dan konsepsinya, meskipun orang-orang tersebut berada dalam satu keluarga. Perbedaan dari berbagai persepsi orang-orang tersebut sangatlah penting didalam perkembangan kurikulum yang lebih baik.

Langkah awal pengembangan kurikulum berangkat dari dimensi kurikulum sebagai ide, yaitu dengan melakukan studi pendapat. Dengan demikian dari beberapa ide yang ada akan diambil mana yang dianggap paling konstruktif, efektif, dan inovatif, tentunya dengan disesuaikan visi-misi dan tujuan pendidikan nasional.

2. Kurikulum Sebagai Suatu Rencana Tertulis

Kurikulum sebagai dimensi rencana tertulis biasanya dituangkan dalam dokumen, berbentuk tulisan dan sebagainya. Hal tersebut banyak mencuri perhatian banyak orang karena sifatnya yang bisa dibaca. Kurikulum dimensi ini merupakan suatu sifat nyata dari kurikulum dimensi ide. Aspek-aspek penting yang perlu dibahas, antara lain: manajemen kurikulum, mengembangkan tujuan dan kompetensi, hasil belajar struktur kurikulum, kegiatan dan pengalaman belajar, organisasi kurikulum, dan sistem evaluasi.

3. Kurikulum Sebagai Suatu Kegiatan

Dimensi kurikulum merupakan (real curriculum) yang sesungguhnya terjadi dilapangan. Peserta didik bisa saja memikirkan kurikulum yang digunakan sebagai ide, akan tetapi apa yang terjadi merupakan kurikulum sebagai (real) nyata. Antara paparan (ide) dan pengalaman yang mungkin sejalan, akan tetapi bisa juga tidak banyak ahli kurikulum yang juga mempertentangkan dimensi ini, dalam dimensi lain apakah didalam suatu kegiatan termasuk kurikulum atau bukan.

Kurikulum diartikan dalam satu kesatuan yang utuh. Jika suatu kegiatan tidak termasuk ke kurikulum berarti semua kegiatan di lembaga pendidikan atau di luar sekolah (seperti program pelatihan profesi, kuliah kerja nyata, dan lain-lain) tidak termasuk kurikulum. Dengan demikian, hasil belajar peserta 
didik di lembaga pendidikan maupun diluar sekolah merupakan refleksi dan realisasi dari dimensi kurikulum sebagai rencana tertulis. Apa yang dilakukan peserta didik dikelas juga merupakan implementasi kurikulum. Artinya, antara kurikulum sebagai ide dengan kurikulum sebagai kegiatan (proses) merupakan suatu rangkaian yang berkesinambungan, suatu kesatuan yang utuh.

4. Kurikulum Sebagai Hasil belajar

Hasil belajar adalah kurikulum, akan tetapi kurikulum bukan hasil dari belajar. Pernyataan ini perlu dipahami dari awal, karena banyak orang yang memeparkan bahwa hasil belajar merupakan bagian dari kurikulum, tetapi kurikulum bukan hanya hasil belajar. Banyak juga orang tidak tahu bahwa arti kurikulum juga dapat dilihat dari dimensi hasil belajar, karena memang tidak dijelaskan secara formal. Begitu pula ketika dievaluasi secara formal tentang kurikulum, pada dasarnya orang selalu mengaitkannya dengan hasil belajar. Sekalipun hal tersebut, evaluasi kurikulum sebenarnya jauh lebih luas dari pada penilaian hasil belajar. Artinya, hasil belajar bukanlah satu-satunya objek evaluasi kurikulum.

5. Kurikulum sebagai disiplin ilmu

Kurikulum memiliki disiplin ilmu diantaranya: prosedur, prinsip, teori dan konsep yang dipelajari sama para pakar kurikulum dan para pendidik yang akan mempelajari kurikulum tersebut pada tingkat pendidikan pertama sampai jenjang perguruan tinggi, semua pendidik wajib mengetahui tentang kurikulum sebagai pembelajaran disuatu pendidikan bertujuan sebagai disiplin ilmu.

6. Kurikulum sebagai sistem

Pendidikan tidak akan pernah terpisah dari sistem kurikulum karena kurikulum adalah merupakan sistem tengtang apa yang mau direncanakan atau disusun untuk dilaksankan pembelajaran mencakup tahap pengembangan, perencanaan, pelaksanaan, perbaiakan, penyempurnaan dan evaluasi. Kurikulum sebagai suatu sistem yang memilik satui tujuan dan komponen yang berkaitan dengan yang lainnya, terkait dalam struktur atau proses yang berfungsi sebagai kesatuan organisasi untuk mencapai tujuan.

Sumberdaya manusia merupakan instrument strategis untuk pengembangan kurikulum yang memiliki koherensi supaya pencapaian tujuan pendidikan dapat terlaksana dengan sempurna melihat realitas kehidupan yang berkembang sangat pesat oleh karna itu perubahan atau pembaharuan kurikulum melihat perkembangan zaman, kebutuhan masayarakat, dan tantangan kemajuan ilmu teknologi dan ilmu penghetahuan. ${ }^{19}$

\section{Menggagas perencanaan kurikulum sekolah unggulan}

Sekolah unggulan merupakan sekolah yang didambakan oleh masyarakat baik masyarakat pengguna jasa pendidikan lembaga sekolah maupun masyarakat pengelola lembaga sekolah. Bahkan banyak sekolah yang menamakan dirinya sebagai sekolah ungul. Namun tidak jelas standart dan kreteria yang di gunakan

\footnotetext{
${ }^{19}$ Baharun, Pengembangan Kurikulum : Teori Dan Praktik (Konsep, Prinsip, Model, Pendekatan Dan Langkah-Langkah Pengembangan Kurikulum PAI). 142
} 
pada sekolah tersebut. Kualitas mutu akan mempengaruhi layak tidaknya predikat uggulan bagi sekolah.

Seharusnya sekolah yang menganggap dirinya sebagai sekolah unggulan bisa memberikan mutu sesungguhnya. Oleh karenanya dua faktor penentu mutu, ialah sebelumnya sudah terpenuhi spesifikasinya dan penuhnya spesifikasi yang diharapkan menurut tuntutan dan kebutuhan pengguna jasa. Pertama adalah mutu sesungguhnya (quality in fact) sedangkan yang kedua mutu persepsi (quality in perception). didalam pelaksanaannya, mutu sesungguhnya (quality in fact) adalah lulusan anak didik dilembaga yang sesuai dengan kualifikasi yang menjadi tujuan lembaga pendidikan, yang dikonkritkan dalam standar kemampuan dasar dalam kualifikasi kemampuan yang diperoleh selama proses belajar. Sedangkan quality in perception pendidikan adalah kepuasan dan bertambahnya minat pelanggan eksternal terhadap lulusan institusi pendidikan.

Oleh karenanya untuk mendapatkan Quality in fact, perencanaan kurikulum bagi sekolah unggul adalah suatu proses awal untuk menyiapkan bentuk gambaran lulusan lembaga sekolah yang sejalan dengan tujuan pendidikan. Dengan demikian kurikulum bukan sekedar rencana pembelajaran dalam arti sejumlah materi pelajaran, melainkan lebih luas berkaitan dengan manajemen atau strategi pengelolaan. Kurikulum yang dimaksud adalah semua yang secara nyata terjadi dalam proses pembelajaran di Sekolah, ${ }^{20}$ baik berkaitan dengan tujuan, isi, metode atau proses belajaran mengajar maupun pada strategi dalam bentuk peninjauan pembelajaran. Oleh karena itu ada keterbatasan dalam konteks waktu yang tidak memungkinkan kurikulum stagnan sepanjang masa. ${ }^{21}$

Di kutip oleh Syarifah rahmah dalam hasbullah, mengatakan Untuk tercapai suksesnya otonomi sekolah di masa depan maka diperlukan kebijakan yang tepat dalam mengembangkan sekolah unggul. Ada beberapa komponen yang perlu dikembangkan yaitu: Pertama, sekolah menentukan sendiri dalam perekrutan karyawan. Kedua, kriteria dan jumlah siswa yang diterima ditentukan sendiri. Ketiga, sistem penilaian kinerja guru dan siswa ditentukan sendiri. Keempat, kegiatan-kegiatan yang dilakukan dalam rangka pendidikan ditentukan sendiri. Kelima, biaya-biaya pendidikan yang ditanggung orang tua siswa ditentukan sendiri. Keenam, metode pembelajaran dan kurikulum yang akan dipakai ditetapkan sendiri. Ketujuh, buku-buku paket yang akan dipakai juga ditetapkan sendiri. ${ }^{22}$

Hal tersebut menunjukkan bahwa sekolah unggulan memiliki kelebihan tersendiri terutama dalam bidang perkembangan segala biadang seperti disebutkan. Maka otonomi sekolah di masa depan baru akan dapat terlaksana jika keseluruhan komponen-komponen yang tersebut di atas dapat terlaksana dengan baik. Sekolah juga harus mempersiapkan semua komponen tersebut secara profesional dan bukan setengah-setengah. Apa bila ketujuh komponen di atas

\footnotetext{
${ }^{20}$ Chusnul Muali, Syaiful Islam, and Muhammad Mushfi El Iq Bali, "Free Online Learning Based On Rich Internet Applications; The Experimentation Of Critical Thinking About Student Learning Style," Journal of Physics: Conference Series 1114 (2018): 1-6.

${ }^{21}$ Ali Khudrin et al., "Implementasi Manajemen Kurikulum Pada Madrasah Diniyah Al-Aziz

Pondok Pesantren Nurul Buda Ii Kabupaten Sleman d.i. Yogyakarta” XV, no. 02 (2008): 15-28.

${ }^{22}$ Syarifah Rahmah, "Mengenal Sekolah Unggulan,” Itqan VII, no. 1 (2016): 11-22.
} 
dapat terpenuhi, maka sekolah tersebut dapat dikatakan sekolah unggul yang berkualitas.

Sekolah unggulan harus merencanakan kurikulum dengan menggunakan beberapa model yang sesuai dengan situasi dan kondisi di lingkungan sekolah, tentunya melalui analis SWOT. Secara konseptual, model kurikulum teknologis atau berbasis kompetensi (KBK). Pembelajaran berbasis kompetensi lebih mengarah kepada penilaian dan belajar dengan menjadikan waktu sebagai variabel yang ditentukan oleh kebutuhan internal dan eksternal. ${ }^{23}$ Kurikulum model teknologis atau yang disebut dengan kurikulum berbasis kompetensi (Competency Based Curriculum) juga menitik beratkan kepada isi kurikulum, akan tetapi berbbentuk kompetensi atau kecakapan dan keterampilan kerja, dengan khas ciri utama pencapaian kompetensi minimal dalam bidang studi tertentu, oleh sebab itu dikatakan berbasis kompetensi. pengajar menyusun KTSP menggunakan pendekatan KBK percaya bahwa pendidikan mentitik fokuskan pada kecakapan pelajar pada kompetensi tertentu. Kompetensi itu merupakan gabungan keterampilan, perilaku, dan pengetahuan yang dapat ditampilkan oleh peserta didik sesudah mereka belajar. Hal tersebut jika diterapkan pada suatu lembaga sekolah bisa jadi sebagai jalan utama untuk menjadi sekolah unggulan.

Perencanaan pembelajaran adalah persiapan pemikiran yang sistematis berupa prinsip-prinsip mengajar yang akan diterapkan dalam situasi khusus terutama dalam proses pembelajaran di kelas. Semakin baik perencanaan pembelajaran semakin baik pula hasil yang dicapai. Situasi pembelajaran umumnya dipengaruhi oleh: faktor pendidik, faktor peserta didik, faktor kurikulum, faktor lingkungan. ${ }^{24}$

Memanfaatkan teknologi informasi. Sekolah unggul harus berusaha untuk membenah dengan mengembangkan proses pembelajaran digital, menambah yang ada guna mengefektifkan program kegiatan pendidikan dan pembelajaran yang lebih maksimal. Teknologi informasi dengan memanfaatkan IT, akan memudahkan siswa dalam belajar. IT juga bermanfaat sebagai sumber belajar yang mudah dan dapat terjangkau di manapun juga. ${ }^{25}$

\section{SIMPULAN}

Manajeman dalam lingkup Perencanaan Kurikulum di sekolah merupakan suatu langkah persiapan dalam pelaksanaan suatu pekerjaan untuk mencapai tujuan perencanaan seperangkat rencana dan pengaturan mengenai isi dan bahan pelajaran serta cara yang digunakan sebagai pedoman penyelenggaraan kegiatan pembelajaran untuk mencapai tujuan pendidikan tertentu.

Sekolah unggulan harus memiliki perencanaan kurikulum yang berbeda dengan sekolah- sekolah biasa tentunya yang menekankan kepada terbentuknya mutu. Oleh karenanya mutu ditentukan oleh dua faktor; quality in fact (mutu sesungguhnya) dan quality in perception (mutu persepsi).

\footnotetext{
${ }^{23}$ J. P. Miler Dan W. Seller. Curriculum Perspectives and Practice. (New Yrk: Longman, 1985). 51 .

${ }^{24}$ Syarifah Rahmah, “Mengenal Sekolah Unggulan”, Itqon, VII.1 2016, 11-22.

25 "Juminto, Syarat Dan Langkah Strategis Sebagai Sekolah Unggulan, Http, Id, Diakses Tanggal 23 Agustus 2016. 12.," n.d.
} 


\section{REFERENCE}

Arif, Muhammad. "Kurikulum Madrasah Dan Sekolah Di Indonisia," no. 1600118036 (2018).

Baharun, Hasan. Pengembangan Kurikulum : Teori Dan Praktik (Konsep, Prinsip, Model, Pendekatan Dan Langkah-Langkah Pengembangan Kurikulum PAI). Yogyakarta: Cantrik Pustaka, 2017.

Fauzi, Ahmad, Hasan Baharun, Akmal Mundiri, and Musolli Manshur, Umar. "ELearning in Pesantren: Learning Transformation Based on the Value of Pesantren." Journal of Physics: Conf. Series 11141114 (2018): 1-6. https://doi.org/10.1088/1742-6596/1114/1/012062.

H. Dakir, Perencanaan Dan Pengembangan Kurikulum, (Jakarta, PT. Rineka Cipta),2004, 117.," n.d.

Hamalik, Oeamar. Manajemen Pengembangan Kurikulum. Bandung: PT Remaja Rosdakarya, 2012.

Hamalik, Oemar. "Dasar-Dasar Pengembangan Kurikulum." Bandung: PT. Remaja Rosdakarya, 2007.

Harjanto, Perencanaan Pengajaran, (Jakarta, PT. Rineka Cipta), 2003, 2.,” n.d.

Hasan Baharun, Zamroni. Manajemen Mutu Pendidikan: Ikhtiar Dalam Meningkatkan Mutu Pendidikan Madrasah Melalui Pendekatan Balanced Scorecard. Tulungagung: Akademia Pustaka, 2017.

J. P. Miler Dan W. Seller. (1985). Curriculum Perspectives and Practice. New Yrk: Longman) , 1985, 51.," n.d.

Juminto, Syarat Dan Langkah Strategis Sebagai Sekolah Unggulan, Http, Id, Diakses Tanggal 23 Agustus 2016. 12.," n.d.

Khudrin, Ali, Implementasi Manajemen, Kurikulum Pada, and Ali Khudrin. "Implementasi Manajemen Kurikulum Pada Madrasah Diniyah Al-Aziz Pondok Pesantren Nurul Buda Ii Kabupaten Sleman d.i. Yogyakarta" XV, no. 02 (2008): 15-28.

Muali, Chusnul, Syaiful Islam, and Muhammad Mushfi El Iq Bali. "Free Online Learning Based On Rich Internet Applications; The Experimentation Of Critical Thinking About Student Learning Style." Journal of Physics: Conference Series 1114 (2018): 1-6.

Peter F. Olivia, Development The Curriculum, (New York: Pearso Education,Inc), 2004, 46-47.," n.d.

Rahmah, Syarifah. "Mengenal Sekolah Unggulan.” Itqan VII, no. 1 (2016): $11-$ 22.

S. Nasution, Asas-Asas Kurikulum, (Bandung : Jemmars), 1982, 5.,” n.d.

S. Nasution, Kurikulum Dan Pengajaran, (Jakarta, PT. Bumi Aksara), 1995, 7.,” n.d. 
Subandijah. Pengembangan Dan Inovasi Kurikulum. Jakarta: PT. Raja Grafindo Persada, 1993.

Supriyanto, Eko. Pengembangan Kurikulum Pendidikan Cerdas Istimewa. Yogyakarta: Pustaka Pelajar, 2012.

Syarifah Rahmah, 'Mengenal Sekolah Unggulan', Itqon, VII.1 2016, 11-22.,’ n.d.

Wina Sanjaya, Kurikulum Dan Pembelajaran, (Jakarta: Kencana Prenada Media Group), 2008, 31., n.d.

Zulfa, Norma Chunnah. "Manajemen Kurikulum Madrasah Aliyah Program Keagamaan.” Jurnal Akuntabilitas Manajemen Pendidikan 1 (2013): 219_ 34. 